\title{
Chris Hann
}

hann@eth.mpg.de

Max Planck Institute for Social Anthropology

Halle (Salle)

\section{THE SEDUCTIONS OF EUROPE \\ AND THE SOLIDARITIES OF EURASIA \\ Keynote Lecture, IUAES Inter-Congress "World Solidarities", \\ Poznań, 27 ${ }^{\text {th }}$ August 2019}

\section{Introduction}

A generation ago, with the end of socialism, Poles and their neighbours in East-Central Europe imbibed the rhetoric of "rejoining Europe." Poland joined the European Union (hereafter EU) in 2004. To judge by the statistics, it has been one of the best economic performers in recent years. Yet here and in the other countries of the Visegrád cooperation, scepticism toward the idea of solidarity at the level of the EU runs deep. Populist politicians thrive and liberal civil society struggles. Many western observers see a contradiction between greedy acceptance of the subsidies provided by the EU (e.g. through agricultural subsidies) and harsh condemnation of "Brussels" for attempting to impose refugee quotas. Can the members of a club deny solidarity whenever it suits their populist political strategies?

Meanwhile, however, "Europe" in the form of the EU retains its seductive appeal to millions of citizens in the Balkans and the eastern half of the continent: to many, of course, for straightforward economic reasons, but also because of the perceived moral superiority of the European brand, characterized by lofty ideals such as freedom, human rights, tolerance, rational secular modes of democratic governance, gender equality, and so on. Whatever the forces currently tearing the EU apart (which have caused the imminent exit of my native country), where else in the contemporary world can solidary solutions to the problems of the planet be forged? 
The answer I shall give in this lecture will be radically Eurosceptic, but not in the usual populist or neo-nationalist sense. Without denying any of the remarkable accomplishments of Europe since classical antiquity, I argue that it is necessary to place them in wider contexts. The landmass should be conceived as Eurasia, of which Europe is an important macro-region; it is an equivalent of China, not of Asia. If we follow anthropologist Jack Goody, abandon once and for all the rhetoric of a "European miracle," and look instead to Eurasian commonalities over the last three millennia, we shall be in a better position to create the geopolitical and moral solidarities urgently needed by humanity.

In the course of the argument, which will move progressively from localized research in this country to the levels of Europe and Eurasia, I shall be raising questions about the nature of our discipline. The contributions it can make to larger issues (including "world solidarities") are manifold. One mode-not very appealing but nonetheless important in my view-is "the anthropologist as spoilsport." This is often connected to ethnographic fieldwork at the micro-levels of social organization. A more respectable name for this mode might be "the anthropologist as comparativist case-worker." I conclude this section by identifying a mode I call "critical utopian," in which the anthropologist engages with long-term history and is not afraid to theorize speculatively at very macro levels of human social organization. Finally I remember a distinguished disciplinary ancestor with close links to this country, though he never learned Polish.

\section{Polish Prologue}

Before I get to Europe and Eurasia, I begin with a personal prologue concerning this country. The theme of solidarity is especially appropriate for the largest anthropological conference ever to take place in this country. At least for persons of my generation, within this country of nearly 40 million (albeit shrinking) and for hundreds of millions more around the world who, like myself, have no kin ties to Poland, the word solidarność and its creative logo evoke a very special period in the recent past. This year in Europe we are witnessing more or less lavish commemorations of the 30th anniversary of the end of communism. The supreme symbol was the breaching of the Berlin Wall, which was soon followed up throughout eastern Europe by the first democratic elections in more than a generation. 
But none of this would have been possible without the bravery and sacrifices of Poles who, continuing a tradition of resistance violently repressed in 1956 and 1970, in the summer of 1980 once again rose up against their illegitimate rulers.

The novelty of the movement which erupted at the shipyard in Gdańsk was that it really did appear to unite the population. Previous eruptions of worker protest had not mobilized intellectual support. When intellectuals protested in 1968, workers remained passive. But in 1980, following years of painstaking bridge-building, Roman Catholic clergymen joined secular intellectuals and the blue-collar masses to forge a united movement. Lech Wałęsa was the unchallenged charismatic leader, but the priests and secularized intellectuals were emphatically in the frame. Even more surprisingly, in this traditionally very patriarchal country, women were also prominent: Anna Walentynowycz, a crane-driver at the shipyard, became an iconic figure in her own right.

When all this started in August 1980 I was taking a break from an ethnographic project in the southeast of this country. ${ }^{1}$ I returned in October and stayed until September of the following year, just a couple of months before the movement was suppressed with the declaration of a state of emergency in December 1981. During my fieldwork I followed the national developments as best I could, mainly through newspapers that enjoyed a high degree of freedom in those months. Because my project was located in the countryside, I was particularly interested in efforts to establish a rural wing of the movement, popularly known as Rural Solidarity. I witnessed a large assembly of the incipient farmers' union here in Poznań at the Opera House, well attended by delegates from all over the country. The general iconography and symbols of the movement were supplemented by images and slogans specific to the countryside (I recall "we alone are feeding the entire nation.") Quite a few participants dressed in traditional folk costumes and attendance at Sunday mass was an obligation for all.

But it is harder to mobilize peasants than it is shipyard workers. Back in the village of Wisłok Wielki, which is about as far away from the booming cosmopolitan city of Poznań as you can get within the current boundaries of the country, the atmosphere was very different. In this community the parish priest repeatedly spoke up from the pulpit in support of Solidarność, but no one seemed interested. The village headman had been

\footnotetext{
${ }^{1}$ See Hann $2016 \mathrm{~b}$ for a full account of the genesis and execution of this project.
} 
decorated by the socialist power holders and had no sympathy with forces out to challenge the government. Inhabitants were of course aware of the drama that was being played out in the major cities, but they did not see how a farmers' union could be of any use to them. I think the most common attitude, no doubt influenced by state-controlled media coverage, was scorn for workers perceived as indulging in irresponsible strike action, while the requirements of the peasant farm ruled out such behavior.

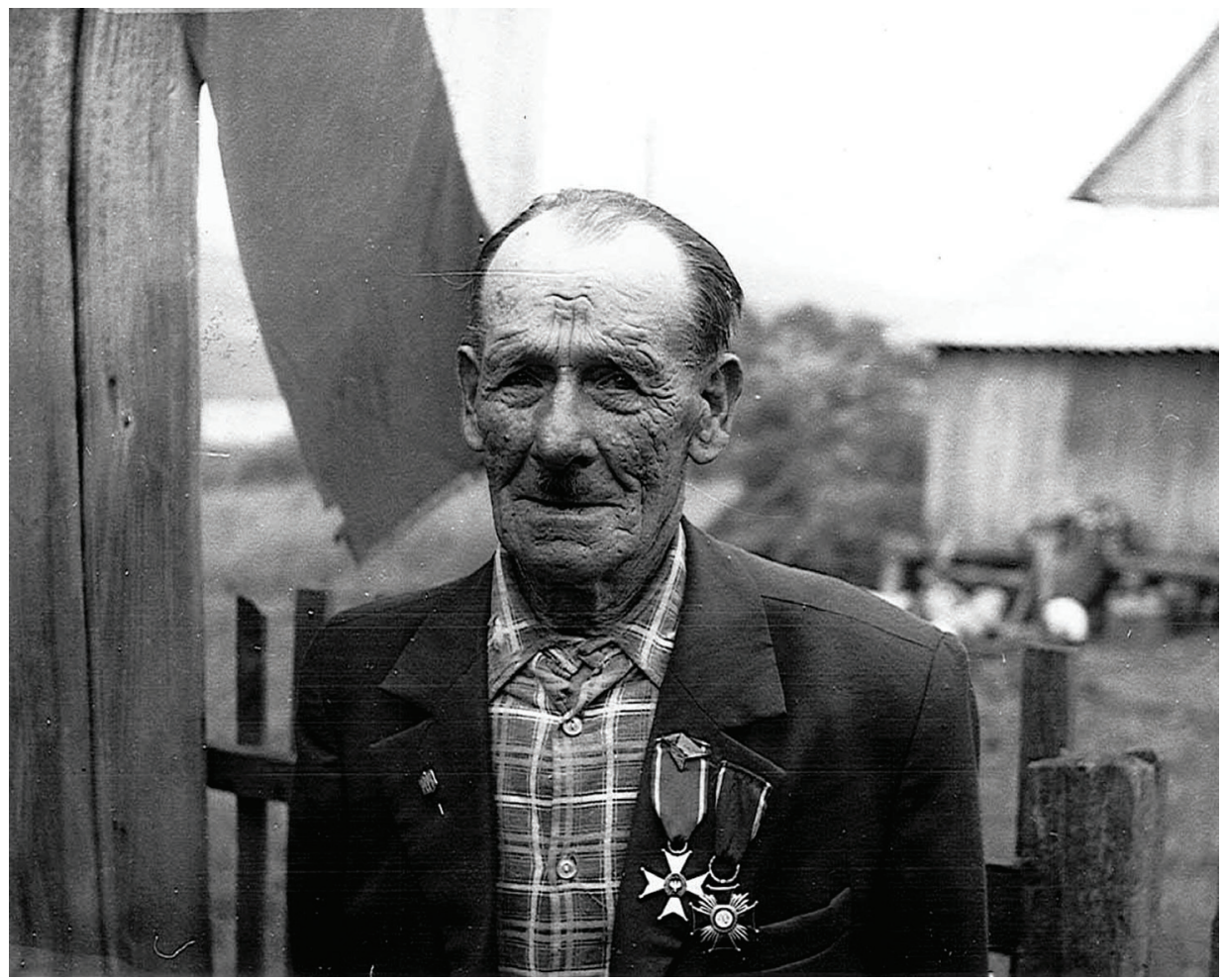

Pic. 1. The Wisłok sołtys who had no patience with Solidarity in 1981 (photo by Chris Hann).

Now, this village was hardly representative. It was populated mainly by poor peasants, who moved there from various regions of south Poland after the original Lemko-Ukrainian inhabitants were driven out in an act of ethnic cleansing in 1947. This is not the place to go into that history (see Hann 1985: chapter 2). Suffice it to say that some members of the minority ethnic group, which was also a minority religious group (Eastern Christian rather than Roman Catholic), were fearful of what the rise of 
a vigorous clerically infused nationalism might mean for their communities, barely a generation after the violence of the 1940s. So Wisłok Wielki was an outlier in terms of its geographical location and ethnic composition. Yet comparable patterns can be found elsewhere, contradicting the illusions that distort many urban intellectual assumptions about solidary communities in the countryside. Let me mention the pioneering research of our host in Poznan today. Michał Buchowski worked in the early 1990s in a village not much larger than Wisłok, Dziekanowice, little more than 20 miles to the north of this city. The region known as Wielkopolska, for centuries strongly marked by German influences, is very different from my region in the south, formerly the Austrian province of Galicia. But in Buchowski's ethnography a decade or so after my own, carried out in very different political circumstances, solidarność was conspicuously absent: both the movement Solidarność (capital S) and the qualities of community cohesion conventionally associated with solidarity (small s). Whereas in my case ethnic differences were a salient cleavage, in Dziekanowice Buchowski highlighted class differences, and in particular the sad fate of the proletariat, former state farm workers, in the brave new world of an emergent capitalist agriculture (Buchowski 2009).

Let me draw this section to a close by asking, with the benefit of nearly 40 years hindsight, what my micro-level observations in Wisłok can contribute to an understanding of Solidarity and solidarity. As far as the capital $\mathrm{S}$ is concerned, I managed to irritate quite a number of people after returning to England by pointing out that, contrary to some of the exaggerated reporting, Solidarność did not in fact mobilize all Polish citizens. Apart from the objections of a nomenklatura elite of Communist Party members, millions of ordinary citizens remained passive. Significant numbers were critical of the movement. Some were fearful, telling me they would prefer a weak communist regime that left them with more scope to cultivate their Eastern Christian traditions than would be possible under a regime of Roman-Catholic, nationalist domination.

Even so, you might say, surely the quantity of this mysterious substance solidarity (small s) was unusually high in Poland in 1980-81. There was some hardship, a lot of inconvenience (lots of time was wasted in queuing for scarce goods). But there was hope and aspiration (yes, these elusive emotions did exist before socio-cultural anthropologists started deploying this vocabulary in the neoliberal era). Several young Polish anthropologists trained a sharp light on the symbolic communication that 
helped the movement to attract so many members and sympathizers. ${ }^{2}$ But my point is that there was also another Poland. Solidarność banners were held aloft even in smaller towns, such as Sanok, the traditional market and administrative centre for Wisłok, where the union led protests against the mass unemployment that affected the town following "shock therapy" in the early 1990s. But south of Sanok you enter the Carpathian Mountains, farming conditions are harsh, and villagers had little sympathy with striking workers. Everywhere in the country, but especially in the east, peasants (this is the best English translation of the Polish chtopy) formed a very sizable proportion of the population-over one third at the time of my fieldwork. By going to a remote place, not on the agendas of the foreign correspondents who flooded into Poland in these years, and reporting on the living conditions and attitudes of "ordinary people," I could puncture a lot of widespread illusions-illusions that other disciplines, such as political science and sociology, tended to buy into. This is an example of what I call "the anthropologist as spoilsport."

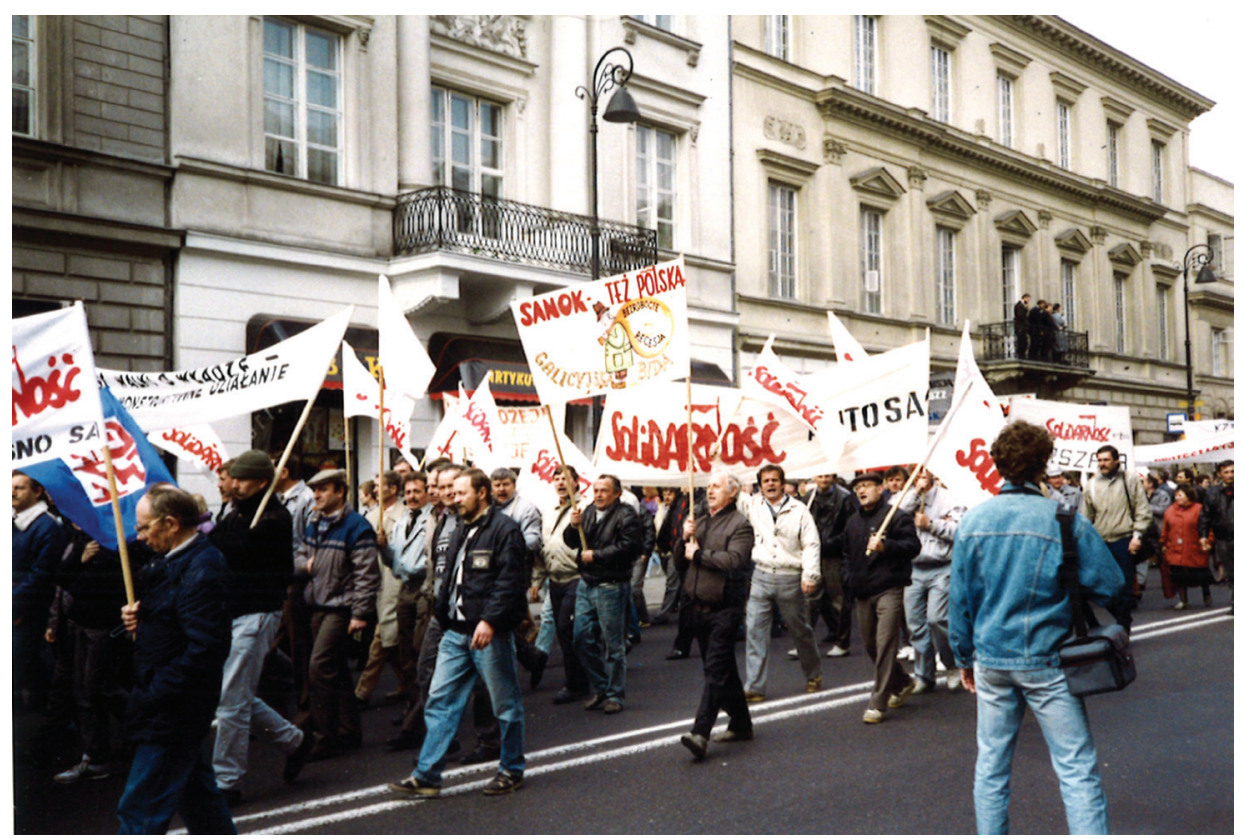

Pic. 2. Workers in Sanok protesting job losses in the early 1990s (photo by Romuald Biskupski).

2 See Kubik 1994 for a rich account of the rituals and symbols of the movement, and in the role played by Pope John-Paul II in national mobilization, and many other factors. See also Mach 1993. 


\section{The Seductions of Europe}

I want to continue in this vein by puncturing illusions at a very different level, that of Europe. To be a spoilsport when it comes to Europe raises more complicated issues-about the history of our world, and about the history and epistemological status of our discipline. But I shall try to keep matters simple by focusing on the essentials. Poland, and eastern Europe more generally in this era following the demise of socialism, is a good place to start for the argument I wish to make.

Alongside the demands for higher wages and specific freedoms, protesters in eastern Europe often invoked more nebulous ideals and encapsulated them in the notion of "rejoining Europe." Perhaps Milan Kundera did more than anyone else in his generation to follow up on the earlier contributions of Czesław Miłosz and spread the sentiment that Marxist-Leninist socialism had removed his country and the rest of Central Europe (Mitteleuropa) from the European civilization to which it had contributed so much over many generations. The themes of captive minds and captive territories were implicit in most western academic writing about eastern Europe throughout the Cold War era. As the climate relaxed behind the "iron curtain," Europe was enthusiastically re-embraced by well-educated "dissidents." The basic message was easy to convey to much larger populations as the pace of change increased and the ancien régime was swept away. Becoming European (again) would mean embracing pluralist politics and capitalist market economy. But what could Europe mean in places like Wisłok? Would Europe convert peasants into capitalized farmers? Would every farm have a tractor, so that very soon Polish villagers would approximate the living standards of their counterparts in Germany?

Alas this did not come to pass. We need to attend to the realities of political economy, which I shall come to in a moment, but the discourses are also significant. For the geographer, the shape of Poland on the map has varied greatly over the centuries, but all of these Polands have been part of Europe. For the historian interested in civilizational consciousness, Poland represents a proud bulwark of western, Latin Christianity, defining itself as superior to civilizations of the east: not only to the Mongols and the Turks who were repelled in the past, but to the Eastern Christians who are immediate neighbours, and who persist as a small minority within the present polity. Conventional definitions of Europe classify those Eastern Christians as Europeans. Europe extends to the Urals. This notion of 
Europe as a continent is, of course, a construction, one with a relatively short history. There is nothing at all to justify it in terms of climate, ecology or geology. But contingent fiat though it may be, it is helpful to recall this familiar notion of Europe as continent when assessing discourses that define it more narrowly, e.g. in terms of western Christianity, or in recent decades, the European Union.

The intellectual attractions of the West for those born and raised in the "other Europe" are as obvious as its material appeal. Dissidents traced modern notions of human rights back to a uniquely European Enlightenment. The superiority of the West was captured in the catch-all concept of civil society, which became so popular in eastern Europe in the 1980s (though in my experience this term never became as popular in Poland as in neighbouring Czechoslovakia and Hungary, even among intellectuals). In the east, by contrast, various forms of feudalism and absolutism persisted, obstructing both liberal forms of society and economic development. According to the familiar stereotypes, Soviet-style socialism represents the monstrous culmination of repressive Oriental society. After the Second World War, under Stalin, this version of socialism penetrated further into the heartlands of the emancipated West than ever before. Hardly surprising, then, that the rhetoric of returning to Europe had a sincere ethical appeal to these populations, over and above the prospect of improving their material situation.

Far be it from me to deny the many solid achievements of this country in the last thirty years. If we set aside the initial dislocation caused by "shock therapy" in the 1990s, the performance of the Polish economy in recent decades has been one of the most impressive in Europe. It was strong enough to come through the global financial crisis almost unscathed. You only need to travel around this city, inspect the shopping malls and new villas in attractive suburban locations, to get a feel for how the middle class is expanding, with consumer tastes converging with those of the West.

However, enter the anthropologist as spoilsport again. Behind the seductions there are darker sides. In the brilliant ethnography of a number of marginalized communities presented by Tomasz Rakowski (2016), the key concept for grasping postsocialist transformations in Poland is not solidarność but degradacja. Regional differences that can be traced back to the era of the partitions have definitely widened. Here in Poznań we are in a boomtown of Polska A, but transformation and convergence are less 
evident in Polska B, comprising the eastern regions that formed part of the Russian and Austro-Hungarian Empires until 1918. Here the norms of patriarchal rurality linger strongly. The legacy of weak socialist regimes' inability to implement collectivization is an agrarian structure that remains the most antiquated on the continent in terms of the fragmentation of both ownership and cultivation. Vast areas of arable land are effectively "outside the market," just as they were a century ago in the world that is documented in a famous work of collaborative social science that has just reached its centenary, The Polish Peasant in Europe and America (Thomas and Znaniecki 1918). These farms are too small to be adapted for capitalist agribusiness, but they still provide a meaningful home to hundreds of thousands of migrant workers. Since Poland's admission to the EU in 2004, a high proportion of them earn their living in Britain. Some money is remitted, but probably proportionately less than was sent from North America to the divided Polish territories a century ago. Public transfers through EU redistribution mechanisms are considerable. But the overall result, for many Poles-as for Hungarians, not to mention much poorer countries such as Bulgaria and Romania-has been disappointing. The economic gulf between West and East has persisted. It has been plausibly argued by Thomas Piketty that the capitalist West has extracted significantly more profit from the postsocialist East than it transfers in the form of regional development subsidies (Piketty 2018). Where would the German automotive industry be without the cheap labour that makes its factories in the Visegrád states so profitable?

The social anthropologist who wishes to investigate these trends at the local level, as I have been for a number of years in the Hungarian county of Bács-Kiskun, south of Budapest, needs to consult other social scientists for an adequate grasp of the macro-level story. We can also draw on theoretical approaches that we have appropriated over the years. I have found Karl Polányi's critique of "market society" especially helpful in understanding why his homeland, Hungary, but also Poland and other states of the region, have elected right-wing "populist" governments in this decade (Hann 2019). This can be theorized in terms of a "double movement." The incessant spread and penetration of the market principle, including the treatment of labour as a "fictitious commodity," just another mobile factor of production, leads eventually to reaction. Society tries to protect itself against neoliberal globalization. The result is governments that incur the wrath of politicians in Brussels and Strasbourg, who launch 
legal processes and threaten sanctions for alleged breaches of European norms of "rule of law." But it is the "negative integration" of the internal market that gives rise to populist resentments in the first place. As Anna Malewska-Szałygin (2016) has shown in her ethnographic work south of Cracow, the success of the party that presently dominates Polish politics can be attributed-at least in part-to the widespread feeling that postsocialist governments have not fulfilled traditional obligations of care and stewardship for the citizens and their economic well-being.

The books of Rakowski and Malewska-Szałygin are excellent examples of how anthropologists working at the micro-level of their own society can contribute to macro-sociological understanding of the precarious condition of Europe today. Many others are doing work of this kind in multiple sites across national borders, e.g. as they investigate labour migration, care chains, and the "Euro-orphans" who suffer as a result of these new mobilities. In conducting such research the anthropologist is not so much spoilsport as indispensable partner for other disciplines in specifying the mechanisms and motivations that drive social and political change. If one does this from a Geertzian, culturalist angle one might term this paradigm "the anthropologist as thick describer." From my own social anthropological angle, the focus on discourses and interpretations should never become too strong. The main goal is to analyze social organization and social structure. We work in small places to grasp the large issues of our time, in the felicitous phrasing of Thomas Hylland Eriksen (1995). I call this "the anthropologist as comparativist case-worker."

To close this section devoted to Europe let me suggest, in the context of an increasingly neoliberal EU, that the only way to forge positive emotional identifications as a basis for solidarity across this macro-region is to return to the idea of "social Europe." I base this to a large extent on my experiences of postsocialism, as a fieldworker in Hungary but also as a resident for the last 20 years of Halle, in the former German Democratic Republic. Even here, in the most wealthy country of the pseudo-continent, the brute fact remains that the penetration of capitalist market economy has not been accompanied by the consolidation of social protection. On the contrary, notions of social Europe prevalent in the last decades of the Cold War have everywhere been diluted. Some economists see this as unavoidable, given the objective conditions prevailing in the postsocialist states when they were admitted to the EU. The gulf was especially great in the cases of Romania and Bulgaria, admitted only in 2007, three years 
after the main expansion. Inequalities between the countries of the new EU were bound to be greater than they were in the original Common Market. The trouble is that encouraging the free flow of capital and labour does not significantly mitigate these inequalities and probably (depending on how one does the calculations) contributes to intensifying and reproducing them. Meanwhile postsocialist citizens, even some of those who appear statistically to be unambiguous "winners" of the transformation, feel nostalgia for the securities and the solidarities of their ancien régime. A hankering for the days when the welfare state functioned far more effectively than it does today was a major factor behind the vote for Brexit in my native country in 2016. In short, I suggest that the project of Europe as a source of positive emotional identification, even a Heimat, as opposed to an arbitrary designation on the map, does not have a future in the population at large unless neoliberal principles are modified by much more serious attention to redistribution, to restoring social solidarity. Intellectuals can enthuse as much as they like about free civil societies and other ideals with their origins in a preindustrial era; but unless the problems of social polarization are addressed, Viktor Orbán and Jarosław Kaczyński, currently still the exceptions, will become the norm for all politicians on the periphery of the EU.

\section{The Solidarities of Eurasia}

I move now to the level of Eurasia, which has been the frame of research in my department at the Max Planck Institute in Halle for the last 20 years. Elsewhere I have done my best to elaborate how we use this concept, drawing in particular on the work of the late Jack Goody (Hann 2016a). Since misunderstandings are still prevalent, let me explain that Eurasia for us does not mean what it means for Russian nationalists, or for the majority of social scientists and historians around the world. It is not a zone at the interface of the two continents of Europe and Asia, beginning perhaps in Polska B and stretching eastwards as far as Mongolia and China. Rather, it comprises the entire landmass between Atlantic and Pacific. It must include the southern shores of the Mediterranean and indeed the littoral of East Africa to the extent that this was integrated into an Indian Ocean world that forms the maritime pendant to the terrestrial connectivity of the landmass that dates back to the Bronze Age. Contrary to Eurocentric 
accounts that privilege a unique breakthrough in Europe (more specifically North-West Europe), in recent centuries, I follow Goody in emphasizing the comparability and commonalities of East and West over millennia. The current rise of China confirms Goody's diagnosis of "alternating leadership," contrary to all those who insist that Renaissance, Scientific Revolution, Enlightenment and Industrialization are the products of a specifically "European miracle." Goody began his anthropological career as an Africanist and no doubt this perspective helped him to perceive what he termed a "Eurasian miracle" (Goody 2010) where so many others were seduced by Eurocentric or Sinocentric models.

I believe that our own discipline in the 21 st century still has a long way to go to overcome the biases to which Goody drew attention. We are still waiting for a follow-up to Eric Wolf's magnificent work of 40 years ago, which I would have liked to re-titled "Eurasia and the People Without History." In this lecture I have no time to probe further into the long-term history, into what I have termed, again drawing on Karl Polanyi, the Great Dialectic of market and redistribution. Let me briefly address a couple of misunderstandings, before returning in conclusion to the issue of solidarity.

The first misunderstanding, very significant for how we are to understand and theorize solidarity, concerns whether Eurasia in my sense is singular or plural. It is both. It is plural in the sense that we can identify distinct civilizational zones, that of China showing the greatest continuity over the centuries. But it is singular in the sense that, when perceived from the perspective of sub-Saharan Africa, or the Pre Columbian New World, or Oceania, there is much to justify treating this landmass as a unity, certainly by the time East and West were linked by the so-called Silk Road over 2000 years ago. The similarities begin in the economy, with the spread of plough agriculture and more individualized forms of property transmission, with consequences ranging from kinship and what Goody termed the domestic domain to the domain of politics and the formation of empires based on new principles of loyalty, elite differentiation, and organized violence. The polities varied greatly. Some of the most creative were city-states rather than empires. Yet it has been persuasively argued that, across Eurasia between ancient Greece and China, we can see comparable ideological developments taking place around the middle of the first millennium BCE. The breakthrough of the Axial Age was neglected by the materialist Goody, but the transformation of 
moral systems and the emergence of new forms of religion can be readily integrated into his vision. Each of the distinct civilizations accomplished the "moral revolution" in its own way (see Halton 2014). Perhaps the term revolution is unwarranted, since the same human potential exists everywhere. But I argue that the new polities in Eurasia had to address the problem of societal cohesion or solidarity on a new scale, with a new potential for universalism because aspiring to include all other human beings (not only those in familiar "we groups" and recognized enemies). They did so by devising new ideological foundations, ranging from the Chinese Emperor's "mandate of heaven" to the Christian injunction to love one's neighbor. While hierarchy undoubtedly increased, principles of inclusion (encompassment) ensured that social life did not become a matter of the survival of the fittest. That is a precondition for and at the same time a key measure of social solidarity. Regardless of the actual extent of the centre's fiscal capacity and actual transfers of resources by private persons or religious institutions, the legitimacy of rulers depended on their paying at least lip service to discourses of solidarity. The solidarities of Eurasia were plural and diverse; but across the belt of agrarian civilizations we can also speak of a new transcendent of social solidarity, a robust universal singular.

Of course, when this modern Eurasia took shape in the late Bronze Age and Iron Age, the polities thus connected did not cover more than a fraction of the land surface. Europe was not integrated, not to mention Siberia. The consolidation of polities capable of penetrating to even the remotest places of the planet's largest landmass was a slow process that culminated in the twentieth century, when the greater part of this surface was governed by regimes that embraced a common ideology. I call this Marxist-Leninist-Maoist socialism. Poland falls close to the western extremity of this world, which disintegrated so rapidly at the end of the last century. But if you follow the perspective of Jack Goody in another late essay (Goody 2003), various forms of "electoral socialism" set the parameters of government in most of the rest of the Europe from 1945 onwards. The precise forms of the Great Dialectic were different-they differed even between Scandinavia and Germany-but redistribution was in the ascendant everywhere. In the era preceding neoliberalism, solidarities were constructed on the basis of the nation-state as welfare state. The last traces of this era in the West can be observed in the Commission led by Jacques Delors in the 1980s and in the social chapters of the Maastricht 
Treaty. After that Treaty came into force in 1992, following the demise of the Soviet bloc, the ideals of "social Europe" were jettisoned. New elites in the postsocialist states, radically anti-collectivist although if many of them were recruited from the former nomenklatura, were complicit agents in this process of erosion.

A generation later, where does the world stand today? Helpful support for my Eurasianist arguments has come since 2016 from North America. The election of Donald Trump to the presidency of the USA is compelling evidence that what I have identified as the principle of solidarity does not carry the same weight or meaning in the world's hegemon. This is still, at the end of the day, a settler society, in which individualist norms carry the greater appeal. As a result, the geopolitical alliances of our age are out of kilter with deeper value preferences. When it comes to the principle of social solidarity, Brussels has more in common with Beijing, and with Moscow and even with Teheran, than it has with Washington. For all the inequalities that the lurch towards the market has brought in China in the last 40 years, communist power holders have been careful to maintain safety-nets, to develop mechanisms of social and medical insurance and pension entitlements, in some ways quite similar to the new forms of solidarity pioneered in western Europe since the late nineteenth century. Contrast this with a settler society in which it is possible to win elections by crusading against the principle of universal health care.

By now you might be wondering how to characterize this kind of anthropology? Are these notions of Eurasian solidarity just playful, dilettante, whacky, or worse, a betrayal of the German taxpayers who provide the funding for all Max Planck Institutes? No, they are not. I think of this mode of anthropological activity as "critical utopian." Of course it is unrealistic. Germany is constitutionally committed to levelling regional differences and there is a complex mechanism of financial transfers to achieve this, but the truth is, confirmed in the aggregate statistics as well as the worm's-eye perspective of the anthropologist, that redistribution does not work very well. Many West Germans were never very happy with the obligation to pay an extra tax, nicknamed the Soli (solidarity), to help to pay for the integration of the former German Democratic Republic. It is about to be abolished. Here in Poland there is still no effective mechanism to counter market forces and ensure that Polska B will ever catch up with Polska A. I predict that these inequalities will be demonstrated yet again in the results of the forthcoming parliamentary elections. 
If effective redistribution cannot be implemented within nation-states, still the main focus for citizenship and emotional attachment, how much less likely is it that residents of the wealthy North-West will agree to the transfers necessary to bring living conditions in Greece up to their level? Not to mention Bulgaria. I have a particular interest in the Visegrád states but, as I noted already, Germany is more concerned to extract value from these countries than to ensure that their citizens have comparable life chances, or receive comparable benefits when they are sick, unemployed or old, etc. What about Moldova, even poorer, but hardly any less European, since it shares its religion, language and political history with an EU neighbor, not to mention its strong links with Russia?

Ah, Russia! Is it perhaps because we have such problems harmonizing conditions within the EU, as presently constituted, that we are obliged to continue demonizing the great power of eastern Europe? When I was young and beginning anthropological research in Hungary and Poland in the 1970s, this was the "other Europe"-but no one doubted that it was Europe. Nowadays we have new generations of EU citizens brought up to conceive of Russia as not belonging to Europe at all. To this extent, the new boundaries are more pernicious that those of the Cold War and they fly in the face of any anthropological understanding rooted in considerations of culture or civilization.

I see these new cleavages as the consequence of a dangerous shift in the long-term dialectic towards the principle of the market. The neoliberal era is unsustainable-ecologically as well as economically and socially. I am optimistic that what presently seems utopian will, within a few decades, come to see the obvious, necessary path. Germans will come to understand that support for Greeks is not generosity, let alone altruism, but a necessary consequence of the European identity to which they proclaim loyalty and on which their own prosperity depends. It will take a little longer but the same logic of stretching solidarity must be extended to those parts of Europe still excluded from the EU-not just the small polities of the Western Balkans but large ones called Ukraine and the Russian Federation. Following the extension of solidarity to Russia, it should not take long to forge a real Eurasian Union that would incorporate the whole of the Old World from Tokyo to Istanbul and Gibraltar. Depending on the situation in Washington, where the principle of solidarity has been historically weak, it might take a little longer to make the transition from "solidarity in Eurasia" to "solidarity on the planet." 
But from the angle of a humanist anthropologist, I cannot envisage any other end-point.

\section{Conclusion: the uncomfortable science}

The argument I have tried to make in this lecture draws on my own intellectual roots in British social anthropology, above all the inspiration of Jack Goody. But it also reflects the mature humanist philosophy of anthropology of another Anglophone giant of our discipline in the last century. Raymond Firth was Bronisław Malinowski's most loyal student. This link was formally sealed when he was awarded an honorary degree by the Jagiellonian University, Malinowski's alma mater, in 1984. Shortly before this honour was conferred on him, Firth gave an address in which he set out his view of anthropology as an "uncomfortable science" (Firth 1981). He was referring primarily to applied anthropology, of the kind that is so important when it comes to the investigation of global solidarities. It is not just a question of being a spoilsport vis-à-vis other disciplines. Researchers of contemporary neo-nationalism (populism) regularly run into ethical dilemmas, when the beliefs and values of those they study differ profoundly from those of the vast majority of anthropologists, including their own. We have to live with this discomfort, even with the awkwardness of being classified as "politically incorrect" within one's own normally solidary academic community. However painful and challenging, I suggest that anthropology must itself remain a populist branch of knowledge in the sense that we try to engage with other people of all kinds, representing and explaining their world views to the best of our ability. This seems to me the most urgent task facing us today. Anthropologists will continue to differ as to how far they should also, in addition to representing and explaining, engage actively to change the beliefs and values that they deplore. Whatever one's position on this issue, I think Raymond Firth's notion of an uncomfortable science can be extended beyond his own examples in the applied anthropology of the last century, to capture the very essence of our discipline. 


\section{REFERENCES}

Buchowski, M.( 2009). Property Relations, Class, and Labour in Rural Poland. In L. Kürti, P. Skalnik (eds.), Postsocialist Europe. Anthropological Perspectives from Home (pp. 51-75). New York: Berghahn.

Eriksen, T.H.( 1995). Small Places, Large Issues. An Introduction to Social and Cultural Anthropology. London: Pluto.

Firth, R. (1981). Engagement and Detachment: Reflections on Applying Social Anthropology to Social Affairs. Human Organization, 40(3), 193-201.

Goody, J. (2003). Sorcery and Socialism. In H. Grandits, P. Heady (eds.), Distinct Inheritances: Property, Family and Community in a Changing Europe (pp. 391-406). Münster: LIT.

Goody, J. (2010). The Eurasian Miracle. Cambridge: Polity.

Halton, E. (2014). From the Axial Age to the Moral Revolution: John Stuart-Glennie, Karl Jaspers, and a New Understanding of the Idea. New York: Palgrave Macmillan.

Hann, C.M. (1985). A Village Without Solidarity. Polish Peasants in Years of Crisis. New Haven: Yale University Press.

Hann, Ch. (2016a). A Concept of Eurasia. Current Anthropology, 57(1), 1-27

Hann, Ch. (2016b). The Wisłok Project, 1978-1985. Lud, 100, 83-92.

Hann, Ch. (2019). Repatriating Polanyi. Market Society in the Visegrád States. Budapest: Central European University Press.

Kubik, J. (1994). The Power of Symbols against the Symbols of Power: The Rise of Solidarity and the Fall of State Socialism in Poland. Pennsylvania: University of Pennsylvania Press.

Mach, Z. (1993). Symbols, Conflict, and Identity. Essays in Political Anthropology. Albany, NY: State University of New York Press.

Malewska-Szałygin, A.(2017). Social Imaginaries of the State and Central Authority in Polish Highland Villages, 1999-2005. Newcastle: Cambridge Academic Publishing.

Piketty, T. (2018, January 16). 2018, l'année de l'Europe. Le blog de Thomas Piketty. Retrieved from http://piketty.blog.lemonde.fr/2018/01/16/2018lanneede-leurope/. Accessed on October 12, 2018.

Rakowski, T. (2016). Hunters, Gatherers, and Practitioners of Powerlessness: An Ethnography of the Degraded in Postsocialist Poland. New York: Berghahn.

Thomas, W.I., Znaniecki, F., W. (1918-19). The Polish Peasant in Europe and America. Chicago: University of Chicago Press. 